\title{
Improvement in Company of Development of Technological Solutions
}

\author{
Daniel Sarcos \\ University of California, United States of America \\ danielsarcos33@gmail.com
}

\begin{abstract}
Summary. Supply chain between the commercial and consultancy is analyzed. This allows to know the process from creating a business opportunity to sell the final product or service. As a result it is concluded that the company under study has some shortcomings in the current model based on multidisciplinary teams. Although effective in the implementation of projects, it is considered that the current methodology is of great complexity, which accommodates the development of proposals to improve the process.

A study of the key to be improved in the supply chain through the SWOT analysis of the same factors ago. Through various interviews and meetings with staff and directors of the company, it is concluded that should improve the chain from three (3) different components: people, processes and technology. Aims to simplify the current model of consulting through the creation of Centres of Expertise and the introduction of the concept of Deliverable. This new methodology industrialization in some way the process for building projects. Each Expertise Center is considered a specialist in one area of activity and not as a multidisciplinary team equipment.
\end{abstract}

Keywords: supply chain consulting, management indicators, centers of expertise.

\section{Introduction}

There are three (3) fundamental aspects to be continually revised in any business consulting: Processes, People and Technology [1]. The company under study is dedicated to consulting and development of technological solutions using CRM software (Managing Customer Relations). The group has offices in Spain, Venezuela and Colombia and executes projects in sixteen (16) countries. Although the market has grown at a steady pace, current methodologies in the core business processes of study does not allow it to be possible to meet the demand. Additionally, current technology that supports much of the generation of knowledge in the business, is being used poorly. In this and due to the growing global economic crisis, the policy has been the need to overhaul the company to reduce costs.

The board intends to undertake a process reengineering project called "efficiency 3.0". This is carried out by an external consultant and its overall objective is to propose and implement improvements that reduce costs and increase business productivity. To achieve this, it is concluded that it is necessary to make proposals for improvement within three (3) fundamental aspects described above. This article aims to present design proposals for improvement in the supply chain to the company and creating a system of indicators to measure the performance of their resources.

\section{Methodology}

The methodology is divided into four (4) stages, all within the company under study [2] ,[3] , [4], [5] ,[6] , [7], [8], ,9] , [10], [11], [12] , [13], ,14], [15], [16], [17]:

1. Analyze the supply chain between Commercial and Consulting.

2. Determine the key factors to improve the supply chain.

3. Propose improvements in the supply chain between Commercial and Consultancy and design tools for the allocation of human resources in the area of consulting.

4. Implement the proposed improvements in the supply chain between Commercial and Consulting. 


\section{Results and Analysis}

In this section the results obtained by using the methodology presented above are exposed.

Phase 1: Analysis of Supply Chain

Figure 1 shows the supply chain of the company under study.

Figure 1. Supply Chain Company in studio

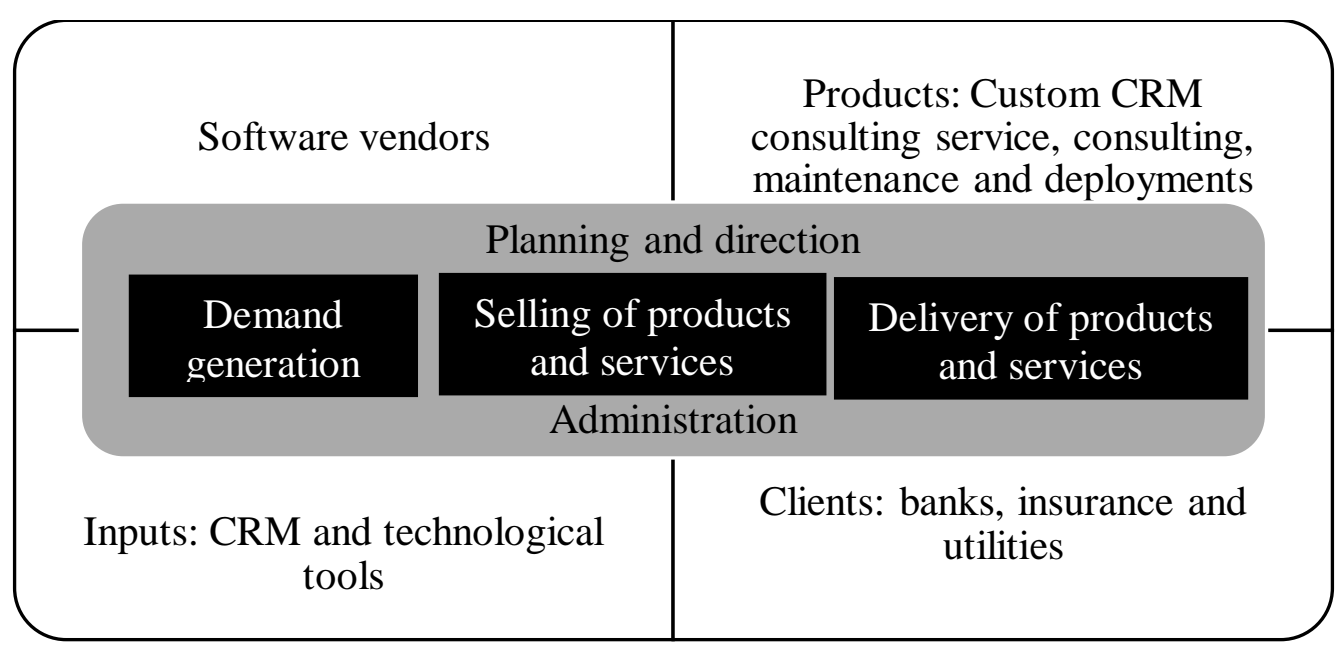

Phase 2: Determination of Key Factors

To identify the strengths, weaknesses, opportunities and threats of the supply chain process internal and external agents were analyzed both. Figure 2 shows the SWOT matrix [4], [18],[19] , [20], [21] ,[22] , [23], [24], [25], [26]

Figure 2. SWOT Matrix for supply chain enterprise study

\begin{tabular}{|c|c|}
\hline strengths & opportunities \\
\hline $\begin{array}{c}\text { Strategic alliance with Microsoft vendor } \\
\text { Highly qualified human resources } \\
\text { Horizontal communication flow } \\
\text { segmented market }\end{array}$ & $\begin{array}{c}\text { New products available for sale } \\
\text { Potential for expansion in the North American } \\
\text { market }\end{array}$ \\
weaknesses & threats \\
\hline $\begin{array}{c}\text { Individual and group no responsibility for the } \\
\text { Little reuse of knowledge and information } \\
\text { generated in previous projects } \\
\text { No measuring process }\end{array}$ & $\begin{array}{c}\text { Marked economic crisis in Spain } \\
\text { High dependence on a single customer } \\
\text { Downsizing }\end{array}$ \\
\hline
\end{tabular}

Based on the analysis of key SWOT Matrix identifies three (3) components around which should focus improvement proposals: Processes, People and Technology. Which are described below:

Processes: improvements are needed in the current business model for the execution and delivery of projects in the area of consulting. Currently the company works with a Model of Multidisciplinary Teams, where an employee performs different roles. It should restructure or evolve the current model to one that increases quality, through group and individual responsibility not traditional projects. A turn is due to emphasize the Deliverable and not the activity that performs the action [4], [24], [25]. 
People: improvements in this component covering everything related to Employees and refines some of its entities and relationships. The concept of KPI (system management indicators) that will be used to measure the performance of resources and firm performance is introduced. On the other hand, the creation of a system to measure the skills of employees to track and control their experience as time progresses is necessary.

Technology: in this regard the creation of a single technology platform that facilitates the management of information throughout the supply chain is necessary. Due to the difficulty of locating previous papers on the current platform, create a technological space and a new methodology capable of improving the management and control of the information developed in the company.

\section{Phase 3: Proposals for Improving and measuring tools}

The following describes each of the proposals for improvement.

\section{Design of a new working model based on Centres of Expertise}

The Centers of Expertise (CE) are the answer to a search of quality, through the (not individual as is traditional) group responsibility and better use of resources by means of intermittent allocating them to reduce efforts required to run a project [3], [4] and [5].

With the implementation of the EC and the emphasis control and measurement Deliverable level, incentives for acceleration and consequent reduction of effort are created. The EC group related roles or one role, have their own portfolio of products or deliverables and their "clients" are the projects both customers and internal. Deliverables are any documents, programming code, record, etc. it is performed by a resource in the company [6] and [7].

The advantages of CE are: concentrated talent and knowledge to implementation and facilitate the transfer of knowledge, foster the creation of affinity groups with similar skills are the incubator of new skills and ideas, offering a capacity of more balanced service with less risk, reduce costs and improve quality through continuous improvement of the Deliverables for which they are responsible, provide Industrial property and linear processes of the company [8] and [9].

The EC should create are: Operations CE, CE Development \& Management Functionality CE, CE and CE Project Control Knowledge \& Quality.

\section{Design a table Skills for evaluation of human resources}

To assign employees to each role within the EC, it is necessary to measure their skills. Under the proposed model, employees are associated with a charge and one or more Roles. Therefore, based on the Role Skills to identify those measurable character needed to carry analysis is performed. It is proposed to divide based Skills thirteen (13) categories:

Database, Communication, CRM, Languages, Industries, Integration, Programming Languages, Processes, Reportadores, $\mathrm{Bi}$, project management tool, Functional and (functional and technical) systems.

\section{Designing a system of performance indicators}

To give measurable character to current business processes, creating a system of performance indicators is proposed. The KPI (Key Performance Indicators) are a set of indicators that apply to all employees and will be a key process performance evaluation element. KPIs are designed based on four (4) different perspectives: Financial, Customer, Processes and Resources.

Phase 4: Implementation and evaluation of improvements

The improvements were implemented for one year in the company under study and its evolution monitored based on a productivity indicator defined as the ratio between successful and generated projects. At the beginning of implementing the indicator value is $30 \%$ a year later this was increased to $95 \%$, representing $75 \%$ improvements in it [5] 


\section{Conclusions}

Supply chain between the commercial and consultancy is analyzed. This allows to know the process from creating a business opportunity to sell the final product or service. As a result it is concluded that the company under study has some shortcomings in the current model based on multidisciplinary teams. Although effective in the implementation of projects, it is considered that the current methodology is of great complexity, which accommodates the development of proposals to improve the process.

A study of the key to be improved in the supply chain through the SWOT analysis of the same factors ago. Through various interviews and meetings with staff and directors of the company, it is concluded that should improve the chain from three (3) different components: people, processes and technology. Aims to simplify the current model of consulting through the creation of Centres of Expertise and the introduction of the concept of Deliverable. This new methodology industrialization in some way the process for building projects. Each Expertise Center is considered a specialist in one area of activity and not as a multidisciplinary team equipment.

Using Skills table model resource allocation is designed through the use of Excel. This proposed model works as support for decision-making in project management. The model is able to assign the best possible combination for each of the roles required in a project resources. Therefore, the selection process and resource allocation will be easier.

The company productivity measured as the ratio between successful and generated projects increases after a year of implementation of the proposed $75 \%$.

\section{$\underline{\text { References }}$}

[1]. Alonso, B. Proyecto Lanka 3.0: Etapa de Diagnóstico. Informe preliminar para la consultoría. Madrid, 2012

[2]. Fuentes M. y Bulmaro A. La gestión de conocimiento en las relaciones académico- empresariales, un nuevo enfoque para analizar el impacto del conocimiento académico. Tesis Phd. Universidad Politécnica de Valencia, 2010.

[3]. Goldratt, E. Cadena Crítica. Ediciones Diaz de Santos. Madrid, 2001

[4]. Grupo Lanka. (2012). 10 Razones Para Confiar en Grupo Lanka. Disponible en Internet: http://www.grupolanka.com/quienes-somos/por-que-somos-diferentes/ consultado 20 de agosto de 2012.

[5]. Grupo Lanka. (2012). ¿Quiénes Somos? Disponible en Internet: http://www.grupolanka.com/quienes-somos/ consultado el 20 de agosto de 2012.

[6]. Jiménez, G. Investigación Operativa I. Centro de publicaciones Universidad Nacional de Colombia. Primera Edición. Manizales, 1999.

[7]. Viloria, A., Vasquez, C., \& Nunez, M. (2009, January). Use of the data envolvent analysis to determine the correct management of the economic resources of a country. In Adaptive Science

\& Technology, 2009. ICAST 2009. 2nd International Conference on (pp. 422-425). IEEE.

[8]. Viloria, A., Urbina, M. C., Rodríguez, L. G., \& Muñoz, A. P. (2016). Predicting of Behavior of Escherichia Coli Resistance to Imipenem and Meropenem, using a Simple Mathematical Model Regression. Indian Journal of Science and Technology, 9(46).

[9]. Amelec, V., \& Alexander, P. (2015). Improvements in the Automatic Distribution Process of Finished Product for Pet Food Category in Multinational Company. Advanced Science Letters, 21(5), 1419-1421.

[10]. Viloria, A., \& Robayo, P. V. (2016). Virtual Network Level of Application Composed IP Networks Connected with Systems-(NETS Peer-to-Peer). Indian Journal of Science and Technology, 9(46).

[11]. Viloria, A., \& Moros, M. A. (2016). Implantation System Brine Recover from Some Chemical Treatment Tanks in a Plant Chlor-Alkali. Indian Journal of Science and Technology, 9(46).

[12]. Viloria, A., \& Parody, A. (2016). Methodology for Obtaining a Predictive Model Academic Performance of Students from First Partial Note and Percentage of Absence. Indian Journal of Science and Technology, 9(46).

[13]. Viloria, A., Acuna, N., Mejia, H., \& Galofre, M. (2016). Determination of the Influence of Thermal Comfort in Care and Concentration of Media Education Students: Case Colombia. Indian Journal of Science and Technology, 9(46)

[14]. Viloria, A., \& Gaitan-Angulo, M. (2016). Statistical Adjustment Module Advanced Optimizer Planner and SAP Generated the Case of a Food Production Company. Indian Journal of Science and Technology, 8(1)

[15]. Viloria, A., \& Lis-Gutiérrez, J. P. (2016). Focus for Interactive Systems Design through the Incorporation of User in the Development Process. Indian Journal of Science and Technology, 9(46).

[16]. Viloria, A. (2016). Commercial Strategies Providers Pharmaceutical Chains for Logistics Cost Reduction. Indian Journal of Science and Technology, 8(1).

[17]. Viloria, A., Wichez, M., \& Acuna, N. (2016). Turnover increased Massive Consumer Products through the Implementation of Design Standards based on the Buyer. Indian Journal of

Science and Technology, 9(46)

[18]. Viloria, A., \& Robayo, P. V. (2016). Inventory Reduction in the Supply Chain of Finished Products for Multinational Companies. Indian Journal of Science and Technology, 8(1).

[19]. Viloria, A., \& Avarez, G. (2016). Dynamics of Public Space Occupation Economic Purposes in Bogota, Colombia. Indian Journal of Science and Technology, 9(46).

[20]. Amelec, V., \& Carmen, V. (2015). Relationship Between Variables of Performance Social and Financial of Microfinance Institutions. Advanced Science Letters, 21(6), 1931-1934.

[21]. Coronado-Hernandeza, J. R., Viloriab, A., Gaitán-Anguloc, M., Mercado-Carusod, N. N., \& Arias-Pereze, J. E. Analysis of Probability of Dropout, Continuation and Graduation through

Markovian Chains of University Students in Bolivar, Colombia.

[22]. Silva, V., \& Jesús, A. (2013). Indicators Systems for Evaluating the Efficiency of Political Awareness of Rational Use of Electricity. In Advanced Materials Research (Vol. 601, pp. 618-

625). Trans Tech Publications.

[23]. Rodriguez, P. E. G., Obando, G. F., Torres, B. E. O., Silva, A. J. V., Muzuzu, B. C. P., Piña, G. C., \& Jimenez, J. A. V. (2014, Augu st). Alianza Académico-Social para el fortalecimiento productivo y comercial de talleres de confección "Categoria A" bajo la metodología de Negocios Inclusivos Universidad Javeriana-Facultades Ingeniería y Ciencias Económicas AdministrativasComunidad USME. In Encuentro Internacional de Educación en Ingeniería ACOFI 2014.

[24]. V Amelec, M Torres, C Vásquez . Validation of the System of Indicators of Sustainability for the Evaluation of the Energy efficiency in Venezuelan Companies Electrical. Researchgate 11 (2), 243-256.

[25]. Torres, M., Viloria, A., \& Vásquez, C. (2010). DIAGNÓSTICO SOBRE LA APLICACIÓN DE LAS FUNCIONES BÁSICAS DE GESTIÓN DE LA INNOVACIÓN EN LA UNIVERSIDAD CENTROCCIDENTAL "LISANDRO ALVARADO". Gestión, 4(2). 
[26]. Montañez-Carrillo, L., Lis-Gutiérrez, J. P., Ariza-Salazar, J., Viloria, A., Gaitán-Angulo, M., \& Balaguera-Jiménez, M. I. (2016). Adaptation of the General Maturity Model of Knowledge Management. International Journal of Control Theory and Applications. ISSN : 0974-5572. International Science Press. Volume 9, Number 44. 